\title{
Acute ischemic stroke in a patient with COVID-19
}

\section{Acidente vascular cerebral isquêmico agudo em paciente com COVID-19 \\ Carla Franco Costa LIMA', Jorge Luis Bezerra HOLANDA' ${ }^{1}$, Mariana Santos Leite PESSOA', Pablo Picasso de Araújo COIMBRA}

Coronavirus disease 2019 (COVID-19) seems to be associated with a strong thrombotic tendency, due to different mechanisms still unknown ${ }^{1}$, which may predispose to arterial and venous thrombosis ${ }^{1,2,3}$. However, risk estimates for these complications are still preliminary ${ }^{1}$.

We report a case of an 89-year-old female patient admitted to the emergency room of a tertiary hospital with right

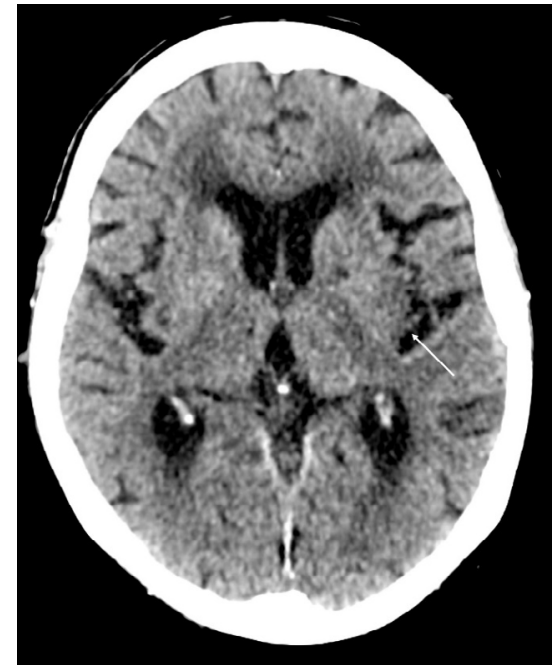

Figure 1. Axial image of cranial computed tomography showing an area of cortico-subcortical hypoattenuation with loss of white-gray differentiation in the left insular region (arrow).

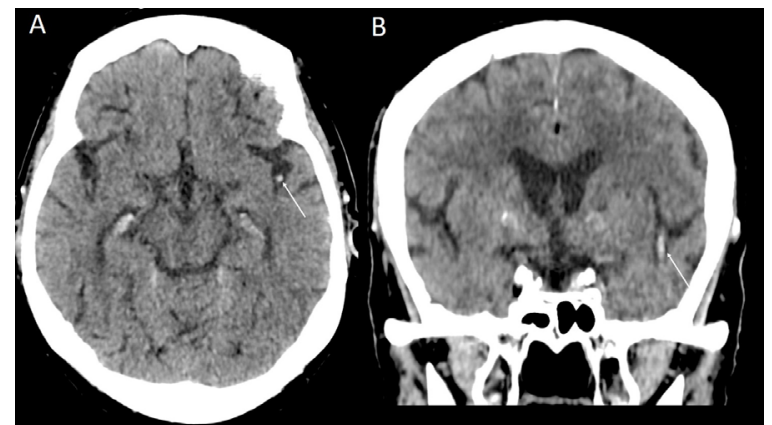

Figure 2. Axial (A) and coronal (B) images of cranial computed tomography compatible with hyperdensity in the left middle cerebral artery (arrows). hemiparesis, aphasia, and dysarthria. Cranial computed tomography (CT) (Figs. 1,2) and cranial CT angiography (Fig. 3) showed findings suggestive of acute ischemic stroke in the area of the left middle cerebral artery. The patient declared having flu-like symptoms for about two weeks, and chest CT findings were suggestive of viral infection (Fig. 4). The rapid test was performed, and the result was positive for SARS-CoV-2.

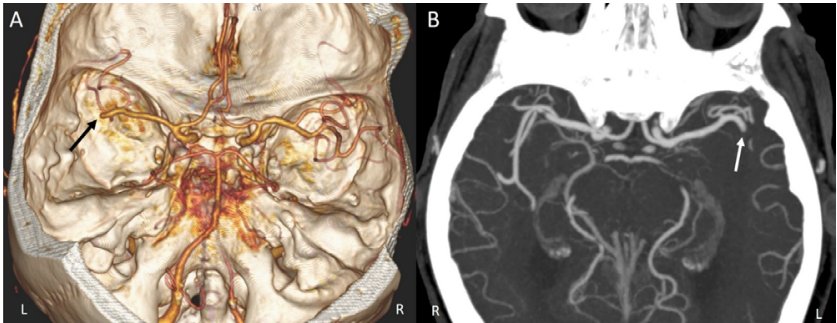

Figure 3. Cranial computed tomography angiography images in $3 \mathrm{D}$ volume rendering reconstruction (A) and axial maximum intensity projection reconstruction (B) showing interruption of contrast flow in the M2 segment of the left middle cerebral artery (arrows).

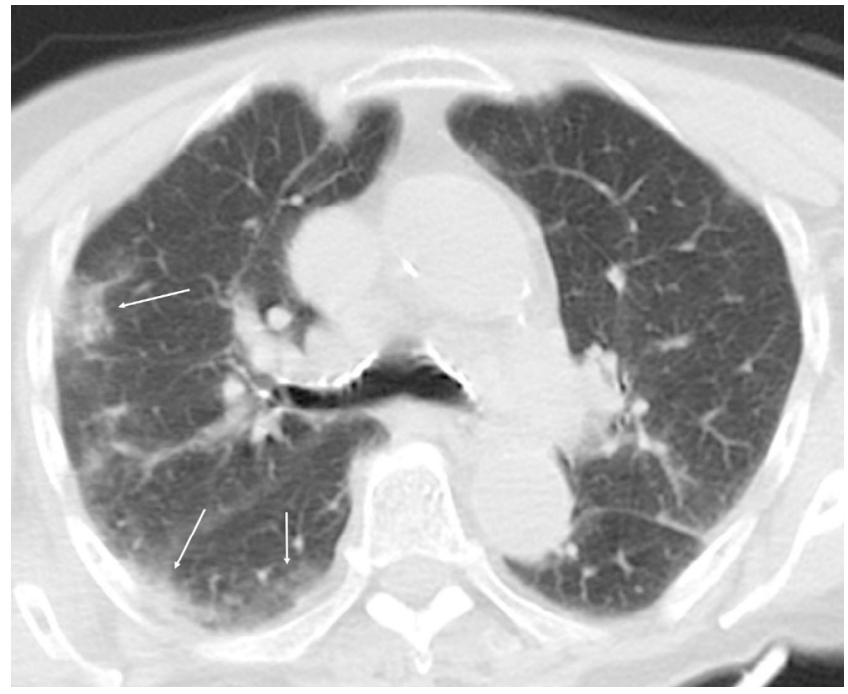

Figure 4. Axial tomography image of the chest with lung window demonstrating peripheral opacity with ground-glass attenuation in the right lung (arrows).

${ }^{1}$ Hospital Geral de Fortaleza, Departamento de Radiologia, Fortaleza CE, Brasil.

Carla Franco Costa LIMA (D) https://orcid.org/0000-0002-7749-3398; Jorge Luis Bezerra HOLANDA (DD https://orcid.org/0000-0001-9334-6411;

Mariana Santos Leite PESSOA (D) https://orcid.org/0000-0003-3495-0779; Pablo Picasso de Araújo COIMBRA (iD) https://orcid.org/0000-0002-7849-9054;

Correspondence: Mariana Santos Leite Pessoa; E-mail: marianaleite170@gmail.com

Conflict of interest: There is no conflict of interest to declare.

Received on May 14, 2020; Received in its final form on May 26, 2020; Accepted on May 29, 2020. 


\section{References}

1. Klok FA, Kruip MJHA, van der Meer NJM, Arbous MS, Gommers DAMPJ, Kant KM, et al. Incidence of thrombotic complications in critically ill ICU patients with COVID-19. Thromb Res. 2020 Jul;191:145-7. https://doi.org/10.1016/j.thromres.2020.04.013

2. Cui S, Chen S, Li X, Liu S, Wang F. Prevalence of venous thromboembolism in patients with severe novel coronavirus
pneumonia.J Thromb Haemost. 2020 Jun;18(6):1421-4. https://doi. org/10.1111/jth.14830

3. Bikdeli B, Madhavan MV, Jimenez D, Chuich T, Dreyfus I, Driggin E, et al. COVID-19 and thrombotic or thromboembolic disease: implications for prevention, antithrombotic therapy, and follow-up.J Am Coll Cardiol. 2020 Apr. [Epub ahead of print]. https://doi.org/10.1016/j.jacc.2020.04.031 